\title{
Construction of Cooperation Sales Credit Risk Assessment System
}

\author{
Pengcheng Zhou, Fei Dai*, Chen Wang, Jiaze Shi, WeiWang \\ Pan-Asia Business School, Yunnan Normal University \\ Kunming, China \\ runxinmachine@163.com, yidoucai@126.com,1084043148@qq.com, shijiaze53@163.com,529073747@qq.com
}

\begin{abstract}
With the deepening of the market economy, business activities between enterprises become more and more frequent. Through investigation, it is found that the credit risk caused by sales has seriously affected the survival and development of enterprises in China. Therefore, it is necessary for Chinese enterprises to adopt scientific and effective methods to solve the risk caused by credit sales. This paper uses the relevant methods of theory of sales credit risk, considers that the evaluation system of sales credit risk no longer depends on individual indicators, constructs a sales credit risk evaluation system combining financial indicators with non-financial indicators, and concludes that the evaluation system of sales credit risk adopts the combination of financial indicators and non-financial indicators. The method can make the sales credit risk assessment more quantifiable and operable.
\end{abstract}

Keywords-Risk, Sales credit, Evaluation system, financial indicators, non-financial indicators

\section{INTRODUCTION}

After the introduction of the socialist market economy in China, the effective allocation of social resources through market supply and demand, price, competition and other mechanisms has played a significant role in the development of the private economy and domestic enterprises' foreign cooperation. However, the emergence of more and more domestic enterprises also faces the expansion of competitive pressure between enterprises. At the same time, more and more enterprises adopt credit sales and other ways to consolidate the target customers. Of course, enterprises using credit sale also face a huge risk of ineffective collection of funds. In recent years, it often happens that enterprises cannot timely collect the payment for goods when they sell goods on credit. Sometimes the poor management of the customers themselves causes it, and some customers escape from the debt maliciously, which causes certain influence and loss to the normal production and operation activities of the enterprises. The control and prevention of sales credit risk lie not in the recovery of accounts receivable after the event, but in the recognition and early warning of credit risk before the event. If the management of enterprise credit sales is not good, it will bring huge enterprise risks (Zhao Xuming, 2015). At the same time, enterprises should pay more attention to the construction of credit management system for the establishment of credit rating (Xu Hong, 2003).

Therefore, this paper attempts to build an evaluation system to prevent the sales credit risk of enterprises by combining the methods of major enterprises to deal with the sales credit risk, combining the financial index with the non- financial index in order to deal with the sales credit risk of enterprises.

\section{LITERATURE REVIEW}

Domestic research on credit sales began in the $21 \mathrm{st}$ century. With the innovation of business model and to the increasing needs of credit sales, credit sales has more and more widely used. So in recent years words "sales research" have also received great attention. Different enterprises have different methods for the framework of the sales credit risk assessment system. In this paper, domestic and foreign scholars are combined to analyze the financial indicators and non-financial indicators used in the construction of the sales credit assessment system to build a widely applicable sales credit risk assessment system.

\section{A. Domestic scholars' views on sales credit risk}

Chinese scholars mainly aim at the existing sales credit risk of the target enterprise. Starting from the actual situation of the enterprise, they analyze the causes of the risk formation or the link of the risk occurrence, and put forward the measures to solve the risk, so as to form a suitable sales credit risk evaluation system.

TABLE I. SUMMARY OF DOMESTIC SCHOLARS' VIEWS ON SALES CREDIT RISK

\begin{tabular}{|c|l|}
\hline $\begin{array}{c}\text { Representative } \\
\text { Personage }\end{array}$ & \multicolumn{1}{|c|}{ The Main Idea } \\
\hline Zhao Xuming(2015) & $\begin{array}{l}\text { Poor management of credit sales will lead to } \\
\text { financial crisis. }\end{array}$ \\
\hline Liu Jing(2011) & Several Important Links in Credit Sales. \\
\hline Xu Hong(2003) & $\begin{array}{l}\text { Expounding sales credit risk from credit } \\
\text { Settlement. }\end{array}$ \\
\hline Zhou Zhenger(2003) & $\begin{array}{l}\text { Introduction of Main Elements of Credit } \\
\text { Risk. }\end{array}$ \\
\hline Zeng Qingquan(2005) & Steps for Building Credit Management System. \\
\hline
\end{tabular}

\section{B. Foreign scholars' views on sales credit risk}

Foreign scholars mainly use various models combined with actual cases to rebuild the sales credit risk model and use a large number of data to test the model, to judge the changes of the indicators in the model, so as to extract the key indicators for the sales credit risk.

* Corresponding author. 
TABLE II. SUMMARY OF FOREIGN SCHOLARS’ VIEWS ON SALES CREDIT RISK

\begin{tabular}{|l|l|}
\hline Representative Personage & \multicolumn{1}{|c|}{ The Main Idea } \\
\hline $\begin{array}{l}\text { Graham Beaver, Peter L. } \\
\text { Jennings (1996) }\end{array}$ & $\begin{array}{l}\text { Using the trend of personal financial } \\
\text { proportion to forecast the credit risk of } \\
\text { enterprises. }\end{array}$ \\
\hline Du Lin (2011) & $\begin{array}{l}\text { This paper discusses the main risk } \\
\text { customer default and risk transfer tools in } \\
\text { credit sales activities in electronic } \\
\text { commerce. }\end{array}$ \\
\hline Haskel Benishay (1996) & $\begin{array}{l}\text { Establishing a Stochastic Model of } \\
\text { Accounts Receivable }\end{array}$ \\
\hline $\begin{array}{l}\text { ChristineA.Parlour, Andrew } \\
\text { Winton (2013) }\end{array}$ & $\begin{array}{l}\text { Camel's model has become the main } \\
\text { model for evaluating financial structure } \\
\text { performance and assets. }\end{array}$ \\
\hline Zeng Qingquan(2005) & $\begin{array}{l}\text { Steps for Building Credit Management } \\
\text { System. }\end{array}$ \\
\hline
\end{tabular}

\section{THE RESEARCH DESIGN}

Based on the theory of sales credit risk and the methods for enterprises to deal with sales credit risk in daily business activities, the main research ideas of this paper are as follows:

\section{A. Relevant Literature Reading And Sorting}

Read relevant domestic and foreign scholars' theoretical research on sales credit risk, sort out and analyze their research results, and select financial indicators and nonfinancial indicators for sales credit risk.

\section{B. The Selection Of Enterprise Financial Index}

In the process of carrying out the daily credit sales business of an enterprise, the growth ability, debt-paying ability and profitability of the enterprise that are most concerned are selected for analysis. And then the above three abilities are subdivided and the financial indicators that can best reflect the above three abilities of the enterprise are selected.

\section{Selection Of Non-fiancial Indicators Of Enterprises}

According to the comprehensive characteristics of enterprise target customers, other important indicators besides financial indicators are selected for analysis, and the non-financial indicators in the sales credit risk are finally determined.

\section{Establish The Sales Credit Risk Evaluation System}

Combined with financial indicators and non-financial indicators, the enterprise sales credit risk model is constructed.

\section{E. The Evaluation Method Of Sales Credit Risk}

In view of the sales credit risk evaluation system, combined with the actual situation of enterprises, a set of effective evaluation methods are developed.

\section{SAlEs CREdit Risk Evaluation SyStem Construction And Evaluation Method SElection}

\section{A. Relevant Literature Reading And Sorting}

By reading the theoretical research of domestic and foreign scholars on sales credit risk, the rationality, availability, and operability of relevant indicators are evaluated accordingly. At the same time, combined with the actual situation of the production and operation process of enterprises to make a bold prediction, the paper screens out the financial indicators and non-financial indicators for sales credit risk. Sales Credit Risk Financial Index System Construction

The construction of this financial index system mainly analyzes the three aspects of enterprise growth ability, debtpaying ability, and profitability. According to the availability of data in each aspect and the intuitive degree of relevant ability, the indicators of the three abilities are subdivided, as shown in table. (1) Enterprise growth ability: this index is not only used to investigate the enterprise through the increase of annual income or through other financing methods to obtain funds to expand the business ability, but also can reflect the target customers in the enterprise life cycle to provide a theoretical basis for the development of credit sales business. (2) Enterprise debt paying ability: this index reflects whether the enterprise has the ability to pay advanced and debt paying ability, which is a key indicator of the healthy development and survival of enterprises. (3) Corporate profitability: this index can directly reflect the ability of the enterprise to obtain profits; profits are also very concerned about with the problem.

TABLE III. SUMMARY OF FOREIGN SCHOLARS' VIEWS ON SALES CREDIT RISK

\begin{tabular}{|c|c|c|}
\hline Category & $\begin{array}{l}\text { Name of } \\
\text { Indicator }\end{array}$ & $\begin{array}{l}\text { Notes to Financial } \\
\text { Indicator }\end{array}$ \\
\hline \multirow{3}{*}{$\begin{array}{l}\text { Enterprise } \\
\text { growth } \\
\text { capability }\end{array}$} & Operating profit growth & $\begin{array}{l}\text { The increase in operating } \\
\text { profit this year/ Total } \\
\text { operating profit of the } \\
\text { previous year }\end{array}$ \\
\hline & Net profit growth rate & $\begin{array}{l}\text { (Net profit of the current } \\
\text { year - net profit of the } \\
\text { previous year)/net profit } \\
\text { of the previous year }\end{array}$ \\
\hline & Growth rate of total assets & $\begin{array}{l}\text { (Total assets at the end of } \\
\text { the period - total assets at } \\
\text { the beginning of the } \\
\text { period)/total assets at the } \\
\text { beginning of the period }\end{array}$ \\
\hline \multirow{3}{*}{$\begin{array}{l}\text { Enterprise } \\
\text { liquidity }\end{array}$} & Liquidity ratio & $\begin{array}{l}\text { Current assets/current } \\
\text { liabilities }\end{array}$ \\
\hline & Asset-liability ratio & $\begin{array}{l}\text { Average total } \\
\text { liabilities/average assets }\end{array}$ \\
\hline & Times-interest-earned ratio & EBIT/interest expense \\
\hline \multirow{3}{*}{$\begin{array}{c}\text { Enterprise } \\
\text { profitability }\end{array}$} & Main business profitability & $\begin{array}{l}\text { (Main business income - } \\
\text { main business cost)/main } \\
\text { business income }\end{array}$ \\
\hline & Return on total assets & $\begin{array}{l}\text { Total profit/average } \\
\text { annual amount of total } \\
\text { assets }\end{array}$ \\
\hline & $\mathrm{PE}$ ratio & $\begin{array}{l}\text { Market price per common } \\
\text { share/earnings per } \\
\text { common share }\end{array}$ \\
\hline
\end{tabular}

\section{B. Sales Credit Risk Non-financial Index System} Construction

In terms of the construction of this non-financial indicator system, relevant indicators are also screened based on the availability and intuitive response of relevant nonfinancial indicators, as shown in table 4. (1) Duration of the cooperative operation: the number of years of cooperation with the customer enterprise is the most intuitive indicator to measure the sales credit limit, the bigger the number of years of cooperation is, the more directly it can explain the customer enterprise has good credit and business activities. 
(2) Management risk preference: the risk tolerance of the top management of the enterprise can directly reflect the strategic development goals of the customer enterprise and enterprise management risk. (3) Change of main managers and core technical workers: the main managers and core technical workers of the enterprise are important power for the long-term development of the enterprise, their frequent demission or post-transfer will bring great uncertainty to the enterprise, the enterprise management risk will also expand with their change. (4) Social responsibility index: this index divides corporate social responsibility index into four aspects as evaluation index: liability management, market responsibility, social responsibility and environmental responsibility. The index has corresponding score under each evaluation of aspect. The sub-score of four indexes will be evaluated to multiply the respective weight and then add together to get final scores of four indexes. The final scores of four indexes will multiply their respective weight and then add together to get final score of social responsibility index.

TABLE IV. THE NON-FINANCIAL INDEX DATABASE OF SALES CREDIT RISK

\begin{tabular}{|l|l|}
\hline Name of a non-financial indicator & Notes on non-financial indicators \\
\hline $\begin{array}{l}\text { Duration of the cooperative } \\
\text { operation }\end{array}$ & $\begin{array}{l}\text { Years of cooperation between } \\
\text { enterprises and customer enterprises }\end{array}$ \\
\hline Management risk preference & $\begin{array}{l}\text { The degree of senior management } \\
\text { tolerates risk }\end{array}$ \\
\hline $\begin{array}{l}\text { Change of main managers and core } \\
\text { technical workers }\end{array}$ & $\begin{array}{l}\text { Enterprise core personnel } \\
\text { demission, post transfer situation }\end{array}$ \\
\hline Social responsibility index & $\begin{array}{l}\text { Comprehensive evaluation of } \\
\text { responsibility }\end{array}$ \\
\hline
\end{tabular}

\section{Selection and Model Construction of Enterprise Sales Credit Risk Assessment Methods}

This paper chooses the analytic hierarchy process as the evaluation method of sales credit risk. Based on the evaluation system of the financial index and non-financial index of sales credit risk, this method includes the quantitative treatment of index weight and mutual relation into the model. In addition, according to the characteristics of different target customers, the Delphi method is selected to modify the weights and test whether the corresponding indicators are applicable to the target enterprises. The final sales credit risk assessment report and assessment score are generated directly by the computer, and the scores and weights under each index are calculated. Finally, the overall score of the customer enterprise is calculated by a weighted average. On the evaluation of the overall score, the Delphi method is also used to divide the evaluation interval of the overall score and confirm the corresponding risk valuation under the corresponding score.

Combining Delphi method and key indicators as well as empowering Key indicators, the new sales credit risk evaluation model is constructed (Table V).

\section{CONCLUSION}

Based on the theory of sales credit risk, this paper constructs an evaluation system of sales credit risk with common practicability. In terms of the selection of index system, this paper adopts the method of combining financial index with non-financial index and strives to make the sales credit risk assessment more quantifiable and operable, which provides a theoretical basis for whether the target enterprise is sold on credit in the daily production and operation process. However, the evaluation system still has some limitations in the specificity, availability and quantitative refinement of indicators. Therefore, in the specific implementation of the sales credit risk assessment process, the evaluation subject can choose more easily obtained and

TABLE V. THE New SALEs Credit Risk Evaluation Model

\begin{tabular}{|c|c|c|c|c|}
\hline $\begin{array}{l}\text { First-level } \\
\text { indicators }\end{array}$ & $\begin{array}{l}\text { Secondary } \\
\text { indicators }\end{array}$ & $\begin{array}{l}\text { Three-level } \\
\text { indicators }\end{array}$ & $\begin{array}{l}\text { Single } \\
\text { propor } \\
\text { tion }\end{array}$ & $\begin{array}{l}\text { Total } \\
\text { propor } \\
\text { tion }\end{array}$ \\
\hline \multirow{9}{*}{$\begin{array}{l}\text { Financial } \\
\text { index }\end{array}$} & \multirow{3}{*}{$\begin{array}{l}\text { Enterprise } \\
\text { growth } \\
\text { capability }\end{array}$} & $\begin{array}{l}\text { Operating profit gro } \\
\text { wth }\end{array}$ & $5 \%$ & \multirow{9}{*}{$60 \%$} \\
\hline & & $\begin{array}{l}\text { Net profit growth } \\
\text { rate }\end{array}$ & $10 \%$ & \\
\hline & & $\begin{array}{l}\text { Growth rate of total } \\
\text { assets }\end{array}$ & $5 \%$ & \\
\hline & \multirow{3}{*}{$\begin{array}{l}\text { Enterprise } \\
\text { liquidity }\end{array}$} & Liquidity ratio & $10 \%$ & \\
\hline & & Asset-liability ratio & $5 \%$ & \\
\hline & & $\begin{array}{l}\text { Times-interest- } \\
\text { earned ratio }\end{array}$ & $5 \%$ & \\
\hline & \multirow[t]{3}{*}{$\begin{array}{l}\text { Enterprise } \\
\text { profitability }\end{array}$} & $\begin{array}{l}\text { Main business } \\
\text { profitability }\end{array}$ & $10 \%$ & \\
\hline & & $\begin{array}{l}\text { Return on total } \\
\text { assets }\end{array}$ & $5 \%$ & \\
\hline & & PE ratio & $5 \%$ & \\
\hline \multirow{4}{*}{$\begin{array}{l}\text { Non- } \\
\text { financial } \\
\text { index }\end{array}$} & $\begin{array}{l}\text { Duration of } \\
\text { the } \\
\text { cooperative } \\
\text { operation }\end{array}$ & $\begin{array}{l}\text { Years of } \\
\text { cooperation } \\
\text { between enterprises } \\
\text { and customer } \\
\text { enterprises } \\
\end{array}$ & $10 \%$ & \multirow{4}{*}{$40 \%$} \\
\hline & $\begin{array}{l}\text { Management } \\
\text { risk preference }\end{array}$ & $\begin{array}{l}\text { The degree to } \\
\text { which senior } \\
\text { management } \\
\text { tolerates risk }\end{array}$ & $10 \%$ & \\
\hline & $\begin{array}{l}\text { Change of } \\
\text { main } \\
\text { managers and } \\
\text { core technical } \\
\text { worker } \\
\end{array}$ & $\begin{array}{l}\text { Enterprise core } \\
\text { personnel } \\
\text { demission, post } \\
\text { transfer situation }\end{array}$ & $10 \%$ & \\
\hline & $\begin{array}{l}\text { Social } \\
\text { responsibility } \\
\text { index }\end{array}$ & $\begin{array}{l}\text { Comprehensive } \\
\text { evaluation of } \\
\text { responsibility }\end{array}$ & $10 \%$ & \\
\hline
\end{tabular}

more targeted indicators to replace the original indicators according to the actual situation and the characteristics of the target enterprise, so as to make the sales credit risk assessment results more credible in a certain range.

\section{ACKNOWLEDGMENT}

The paper is supported by Yunnan Normal University Doctoral Research Project(XJB2018122007).

\section{REFERENCES}

[1] Zhao Xuming. Prevention and management of enterprise credit risk [J]. Economic Guide, 2010 (09): 68-69.(In Chinese)

[2] $\mathrm{Xu}$ Hong. Perfecting the internal control system is the premise of sound operation of financial industry [J].Heilongjiang Finance, 1997 (09): 21-24 (In Chinese)

[3] Wu Dingyu, Liu Jing. Discussion on Enterprise Credit Sales Management Strategy [J]. Packaging World, 2011 (01): 15-18.(In Chinese)

[4] Zhou Zhenger. How to Avoid Credit Sales Risk [J]. Economic Forum, 2003 (11): 48 (In Chinese)

[5] Zeng Qingquan, Ma Lu. Constructing credit management system of enterprise accounts receivable to effectively solve the predicament of enterprise accounts receivable [J]. Journal of Guangxi Institute of Technology, 2005 (S3): 166-169 (In Chinese) 
[6] Graham Beaver,Peter L. Jennings. The abuse of entrepreneurial power-an explanation of management failure?[J]. Strategic Change, 1996,5(3): 152-164

[7] Du Lin. Research of risk management of credit sales in Ecommerce[P]. Artificial Intelligence, Management Science and Electronic Commerce (AIMSEC), 2011 2nd International Conference on, 2011
[8] Haskel Benishay. Inflow-Stock-Outflow time series, stochastic lag and disaggregation: a note[J]. Journal of Applied Probability,1970,7(1):234-239

[9] Christine A. Parlour,Andrew Winton. Laying off credit risk: Loan sales versus credit default swaps[J]. Journal of Financial Economics,2013,107(1):25-45

[10] Vinod Venkiteshwaran. Do asset sales affect firm credit risk? Evidence from credit rating assignments[J]. Managerial Finance, 2014,40(9): $: 903-927$ 